IZA DP No. 8410

Migration, Economic Crisis and Adjustment in the UK

Ken Clark

Stephen Drinkwater

Catherine Robinson

August 2014

Forschungsinstitut zur Zukunft der Arbeit Institute for the Study of Labor 


\title{
Migration, Economic Crisis and Adjustment in the UK
}

\author{
Ken Clark \\ University of Manchester \\ and IZA \\ Stephen Drinkwater \\ WISERD, Swansea University \\ and IZA
}

\section{Catherine Robinson}

University of Kent

\section{Discussion Paper No. 8410 \\ August 2014}

\author{
IZA \\ P.O. Box 7240 \\ 53072 Bonn \\ Germany \\ Phone: +49-228-3894-0 \\ Fax: +49-228-3894-180 \\ E-mail: iza@iza.org
}

Any opinions expressed here are those of the author(s) and not those of IZA. Research published in this series may include views on policy, but the institute itself takes no institutional policy positions. The IZA research network is committed to the IZA Guiding Principles of Research Integrity.

The Institute for the Study of Labor (IZA) in Bonn is a local and virtual international research center and a place of communication between science, politics and business. IZA is an independent nonprofit organization supported by Deutsche Post Foundation. The center is associated with the University of Bonn and offers a stimulating research environment through its international network, workshops and conferences, data service, project support, research visits and doctoral program. IZA engages in (i) original and internationally competitive research in all fields of labor economics, (ii) development of policy concepts, and (iii) dissemination of research results and concepts to the interested public.

IZA Discussion Papers often represent preliminary work and are circulated to encourage discussion. Citation of such a paper should account for its provisional character. A revised version may be available directly from the author. 
IZA Discussion Paper No. 8410

August 2014

\section{ABSTRACT}

\section{Migration, Economic Crisis and Adjustment in the UK ${ }^{*}$}

We examine changes in migration to the UK in the period leading up to the Great Recession and in its immediate aftermath. In so doing, we pay particular attention to the changing countries of origin of recent migration flows to the UK, especially in relation to migration from other parts of the EU. The evolving patterns of migrants' socio-economic characteristics and labour market outcomes are also analysed, including how these relate to changes in the economy and migration policy. Finally, we review evidence on the impact of migration on the UK labour market and government finances.

JEL Classification: F22, J61

Keywords: migration, policy, economic performance, United Kingdom

Corresponding author:

Stephen Drinkwater

WISERD

Swansea University

Richard Price Building

Singleton Park

Swansea

United Kingdom

E-mail: s.j.drinkwater@swansea.ac.uk

\footnotetext{
* Material from the Quarterly Labour Force Survey is Crown Copyright and has been made available by the Office for National Statistics (ONS) through the UK Data Service. We are also grateful to comments on an earlier draft from Martin Kahanec and an anonymous referee, as well as from participants at an IZA workshop on "EU Enlargement and Labor Markets: Migration, Crisis and Adjustment in an Enlarged (E)MU II" in Budapest. The views expressed in this study and errors therein are those of the authors.
} 


\section{Introduction}

The United Kingdom (UK) provides a fascinating case study with which to examine international migration flows during and immediately after the Great Recession. This is because the UK experienced both a rapid growth in immigration, especially following European Union (EU) enlargement in 2004, and a particularly severe fall in output in the wake of the financial crisis of 2008. The UK was one of only three countries to essentially grant open access to migrants from the eight "Accession" countries (EU8) in 2004 and between December 2003 and December 2004 net migration to the UK increased by $66 \%$ from 148,000 to 245,000 . At least two-thirds of this increase can be accounted for by migrants from the EU8. Furthermore, following a 15 year period of sustained economic growth of around 3\% per annum, the UK economy was severely affected by the global financial crisis that began in 2007. Real GDP fell by over 6\% between early 2008 and mid 2009, with sectors such as banking being particularly affected. However, the decline in employment over this period was more muted since the employment rate fell by only 2 percentage points, with Gregg and Wadsworth (2010) suggesting that this discrepancy was due to factors such as the pro-active policy measures introduced by the UK government and modest wage settlements at the beginning of the recession.

Historically the UK has experienced net emigration although this reversed in the mid1980 s as a result both of policy changes, improvements in the opportunities for migrants in the UK and a reduction in emigration (Hatton, 2005). In international terms, even after the very large waves of migration in the 2000-2010 period, the UK has net migration rates, expressed as a proportion of the population, below those of traditionally 'immigrant' countries such as Australia, Canada and the US and also below those of Spain and Italy, but higher than those of other Northern European countries such as France, Germany and Scandinavia. Within this context, we present a range of statistics associated with international migration in relation to the UK and attempt to draw linkages with the economic fluctuations that have been observed, as well as with changes to migration policy.

Following a brief review of the UK's recent economic performance and the main changes to migration policy, we examine how migration flows to the UK have evolved over the past decade or so, focusing primarily on migrants from other parts of the EU. In addition to tracking changes in the volume of immigrants, the origin and composition of migration flows will also be analysed. The stock of immigrants in the UK will then be considered in relation to areas of origin, socio-economic and labour market characteristics. This is followed by a discussion of the impact of immigration on various aspects of the economy, focusing particularly on the labour market and public finances.

\section{Recent Changes in the UK Economy and Migration Policy}

This section provides an overview of recent developments in the UK economy and migration policy in the UK. As a result of the integrated nature of the global financial system, it will also briefly discuss recent changes in the international economy and comment on the situation that has emerged following the Great Recession. The continuing crisis within the Eurozone has also slowed the recovery in many EU member states and this has also had an impact on the UK economy. Migration policy 
in the UK is also influenced by international (especially EU) regulations and directives. However decisions that the UK government has taken with respect to the degree of openness of its borders, especially following recent EU enlargements, has had a major effect on migration flows.

The UK economy is best considered in an international context, especially in comparison to the four other large EU economies (France, Germany, Italy and Spain). The economic slowdown that followed the financial crisis of 2007 resulted in most nations seeing a quite substantial fall in growth in the 5 quarters that followed the start of 2008. The UK experienced one of the most severe declines, with growth falling by over 6 percentage points between the first quarter of 2008 and second quarter of 2009. The extent of the fall may be explained to some extent by the strong growth experienced between 2000 and 2007. During this period, the UK grew at almost the same rate as Spain - with both countries also experiencing a rapid increase in immigration over this period (Kangesnemi et al., 2012) - and far faster than Germany, France and Italy. The UK has seen growth fluctuate since, with the slight recovery seen in 2009 and 2010 followed by a dip and then a return to fairly strong growth.

The change in employment in the UK generally remained positive up until 2009, albeit at a relatively low level since the annual increase in employment was around $1 \%$ for most of the 2000s. In contrast, Spain experienced very large changes in employment over the period, with an average growth rate of around $3.5 \%$ per annum in the period prior to 2008. The UK unemployment rate remained relatively constant at around $5 \%$ until the middle of 2008, which was relatively low by European standards. However, from mid-2009 there has been some convergence towards the EU average; the unemployment rate increased from just over $5 \%$ in the second quarter of 2008 to almost 8\% by the second quarter of 2009 and then hovered around this level for some time. In terms of wage trends, whilst nominal wages in the UK appear to have climbed steadily over the past decade, slowing only in 2010-2011, real wages showed some growth in the early 2000s but were relatively flat between 2002 and 2009. From 2009, there has been a decline in the median level of real weekly wages, with real earnings returning to around their 2000 level. $^{1}$

The New Labour government of Tony Blair which came to power in 1997 ushered in a shift in UK immigration policy. The main thrust of this change was to recognise the contribution of economic migration to the economy and to allow more migrants to enter the country through the work permit route - essentially a licensing system enabling employers to recruit workers from countries outside the EU. The most dramatic illustration of the change in policy regime, however, was the decision to allow migrants from the new accession countries to enter the UK in May 2004. Amongst EU countries, only the UK, Ireland and Sweden allowed free movement of EU8 nationals across their borders. ${ }^{2}$ Research commissioned by the government had predicted that the resulting flows would be small (Dustmann et al., 2003); whilst it is

\footnotetext{
${ }^{1}$ See Gregg and Machin (2012) for a more detailed discussion, including that real wage falls across the distribution of wages are not a usual feature of recessions in the UK.

${ }^{2}$ Access to the UK labour market was more or less liberalised for EU8 migrants from May 2004. New migrants coming to work in the UK were meant to register on the Worker Registration Scheme (WRS) within one month of taking up employment in the UK. However, it is thought that a relatively high proportion of those that should have registered, likely to be around a third, failed to do so (Drinkwater et al. 2009).
} 
in fact claimed that the government's decision led to the largest single immigration wave in UK history (Bauere et al., 2007). ${ }^{3}$ By far the largest number of EU8 migrants to the UK came from Poland, with over 250,000 entering between May 2004 and June 2006 compared to a Polish-born population of around 60,000 according to the 2001 Census (Drinkwater et al., 2009). ${ }^{4}$

It is clear that the scale of EU8 migration post-2004 took the UK government by surprise and that subsequent policy was in part a (political) reaction to concerns raised by the perception promulgated in sections of the media that in many parts of the UK resident workers were now competing in the labour market with the newcomers. Subsequent policy towards Bulgarian and Romanian workers who faced restrictions on their movement to the UK when their countries joined the EU in 2007 was one reaction. Provision for Bulgarian and Romanians to come to the UK to do mainly low-skilled agricultural work has been made under the Seasonal Agricultural Worker Scheme (SAWS) and Sector Based Schemes (SBS) but since 2007 this has been available only to Bulgarians and Romanians at the expense of workers from other countries, particularly those from Eastern Partnership countries (e.g. Ukraine, Moldova and Belarus) who comprised a large proportion of those allowed to work in the UK agricultural sector between 2000 and 2007. In addition to entering the UK labour market via these schemes, Bulgarians and Romanians could also work in the UK prior to January 2014 if they were self-employed, as was the case with migrants from EU8 countries in the lead-up to the 2004 enlargement. As well as the legitimately self-employed, it has also been argued that there are a growing number of immigrants, including Bulgarians and Romanians, who are working effectively as paid-employees as a result of being registered as self-employed in the UK.

The introduction of the Points Based System (PBS) in 2008 can also be seen as a wider response to the challenges of the UK's responsibilities under EU treaties and law. The PBS which deals with economic and educational migrants from outside the European Economic Area (EEA) was the government's attempt to balance the, potentially competing imperatives of firstly being seen to be "in control" of the UK's borders and secondly enabling UK business to access the skilled labour force it needs. In effect, the PBS replaced the previous system of immigration by compressing over 80 work and study routes into the UK into five main tiers (Devitt, 2012). The explicit intention was to increase the average skill level of migrants from outside the EEA and the scheme awards points to migrants for educational qualifications and English language ability as well as targeting a list of "shortage" occupations. These occupations have to be deemed sufficiently skilled by the Migration Advisory Committee (MAC) to appear on the list. ${ }^{5}$

\section{Recent Migration Flows to the UK}

This section initially uses the Long-Term International Migration (LTIM) estimates, which are produced by the Office for National Statistics (ONS), to examine recent

\footnotetext{
${ }^{3}$ However, the forecasts of migration flows were based on the assumption that Germany and other EU member states would open their borders to EU8 migrants at the same time as the UK.

${ }^{4}$ Estimates from the most recent Census indicate that the number of Polish migrants living in England and Wales had risen to around 580,000 by March 2011.

${ }^{5}$ Devitt (2012) discusses the process by which occupations appear on the list. Recent amendments that have been made to the PBS imply that the points aspect of the system is now more muted.
} 
migration flows to and from the UK. These are the headline/official migration figures that are reported for the UK in terms of year-on-year changes to gross and net migration flows and are available on a consistent basis back to 1991. Despite being the main method of measuring immigration to the UK, there are a number of criticisms of the LTIM data. ${ }^{6}$ These include that the estimates only relate to long term migration - those intending to stay in the UK for at least one year - which implies that they only partially cover the extent of migration to the UK. Given that the data are mainly obtained from a survey - the International Passenger Survey - that only samples a relatively small number of migrants, there are also concerns over the accuracy of the estimates. This is especially the case with regards to migrants from particular countries/regions or with particular characteristics. ${ }^{7}$ There are also some definitional issues such as whether students should be included in the estimates, with some organisations - including universities - arguing that students should be reported separately from other long-term international migrants.

Figure 1 shows that long-term immigration rose rapidly between 1997 and 2004, from just over 300,000 to almost 600,000 per annum, but has levelled off since then. ${ }^{8}$ This is to some extent due to the impact of the recession in the UK but other factors are also likely to have had an influence, including policy changes such as the introduction of the PBS. Emigration also increased from the late 1990s but not as sharply as immigration and has also dipped since 2008. As a result, net migration has increased quite substantially, with 1992 the only year in the last two decades when there was a net outflow of people from the UK. In particular, net migration rose from 48,000 in 1997 to 252,000 in 2010, before falling back to 216,000 in 2011.

Figure 1: Estimated Long-Term Immigration and Emigration for the UK

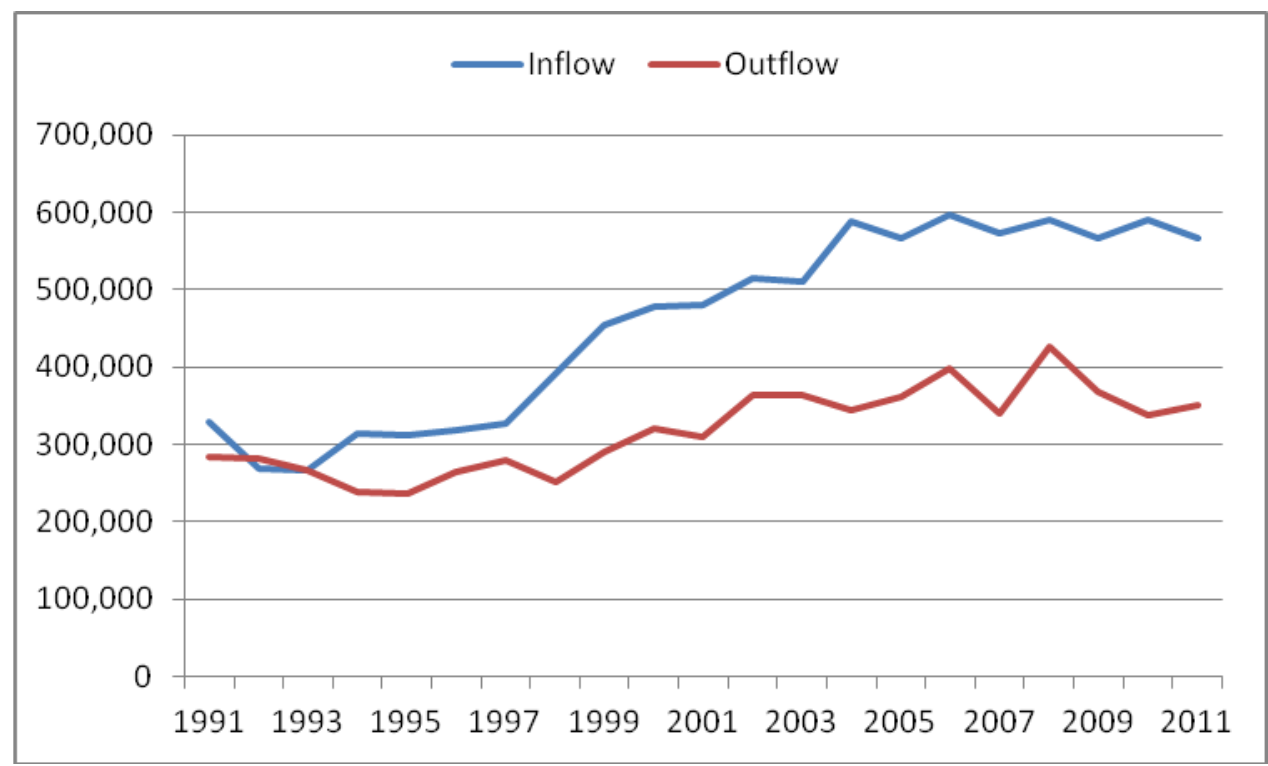

Source: ONS

\footnotetext{
${ }^{6}$ For further information on the construction of the LTIM estimates, see ONS (2012).

${ }^{7}$ 95\% confidence intervals for LTIM estimates are now reported by the ONS.

${ }^{8}$ These estimates include British citizens, see Figures 3 and 4 for the extent of out and return migration by Britons.
} 
The estimates for inflows into the UK from 2000 to 2011 are broken down into reasons for migrating to the UK in Figure 2. It can be seen that students are currently the largest group, followed by those moving to the UK for a job. The relative importance of these two reasons has changed since 2007, following an estimated fall of around 50,000 in the number arriving with definite job offers and with migrants entering through the study route continuing to experience strong growth up to 2010. The trends in the other reasons have been more stable, although there has been a noticeable decline in the 'other' category since 2002.

Figure 2: Reason for Immigration to the UK

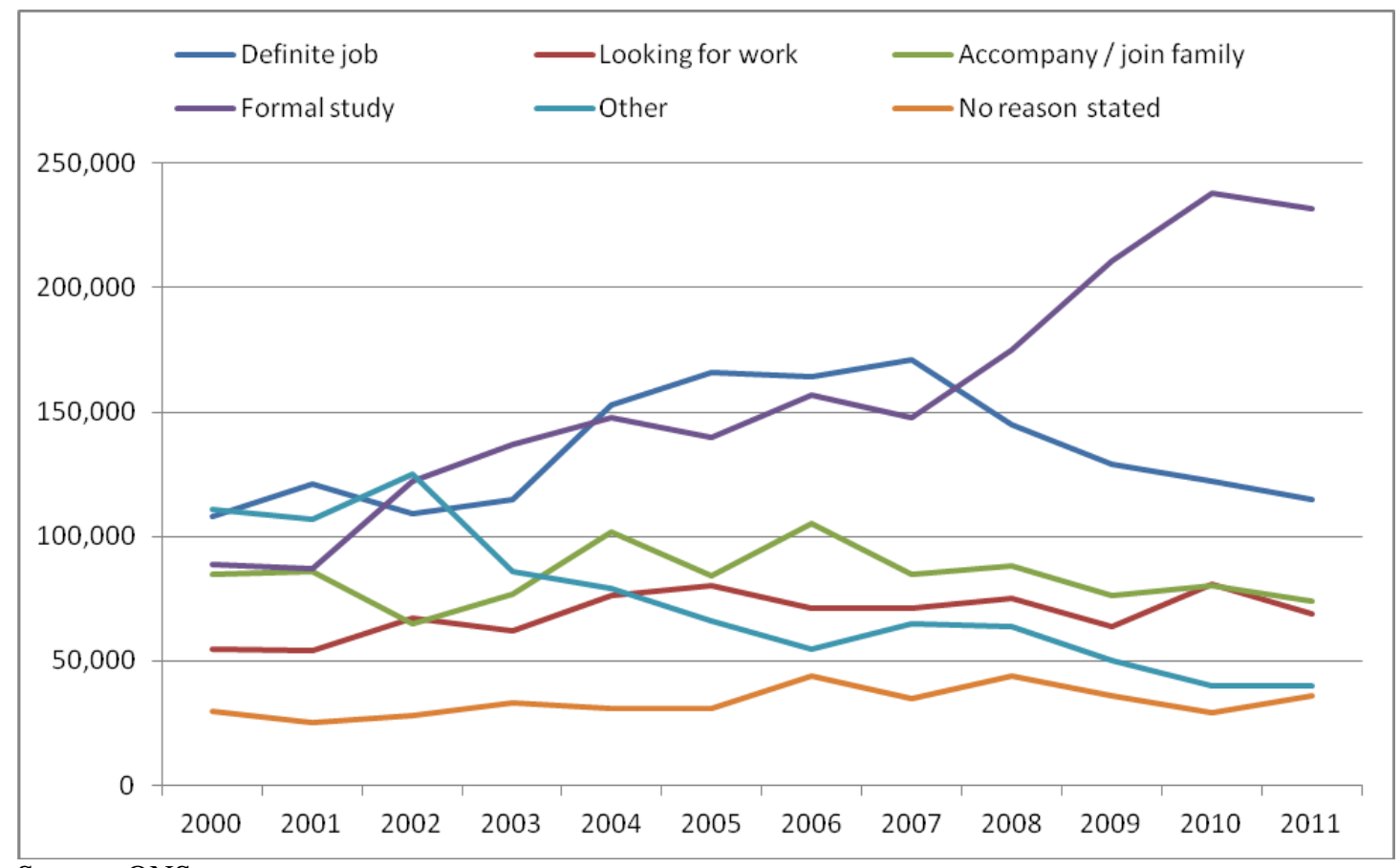

Source: ONS

Figure 3 shows inflows into the UK over the same period according to their region of citizenship. Four citizenship groups are identified. These are British, EU14, EU12 and non-EU. ${ }^{9}$ The most noticeable change in inflows within this period is observed for migration from the EU12. There were no estimates for inflows from these countries prior to 2004, but over 50,000 long term migrants were estimated to have arrived in the UK in the first year of accession. According to the TIM estimates, long term immigration from the EU12 peaked at 118,000 in 2007 and then dipped below 100,000 in 2009 and 2011. Long term immigration from EU14 countries rose fairly steadily between 2001 and 2008, reaching 90,000 in the latter year. Long term immigration from non-EU countries was highest in 2004, when it reached 370,000. Although migration to the UK from outside the EU has declined since then it has remained at over 300,000 in each of the subsequent years. Finally, return migration by British citizens has fluctuated within the range of 70,000 to 110,000 .

\footnotetext{
${ }^{9}$ Table A1 in the Appendix contains a list of the countries in the EU14 (pre-2004 member states, excluding the UK) and EU12 (countries joining the EU between 2004 and 2007) groupings, as well as the main countries of origin in the non-EU category.
} 
Figure 3: Long Term Immigration to the UK by Citizenship Group

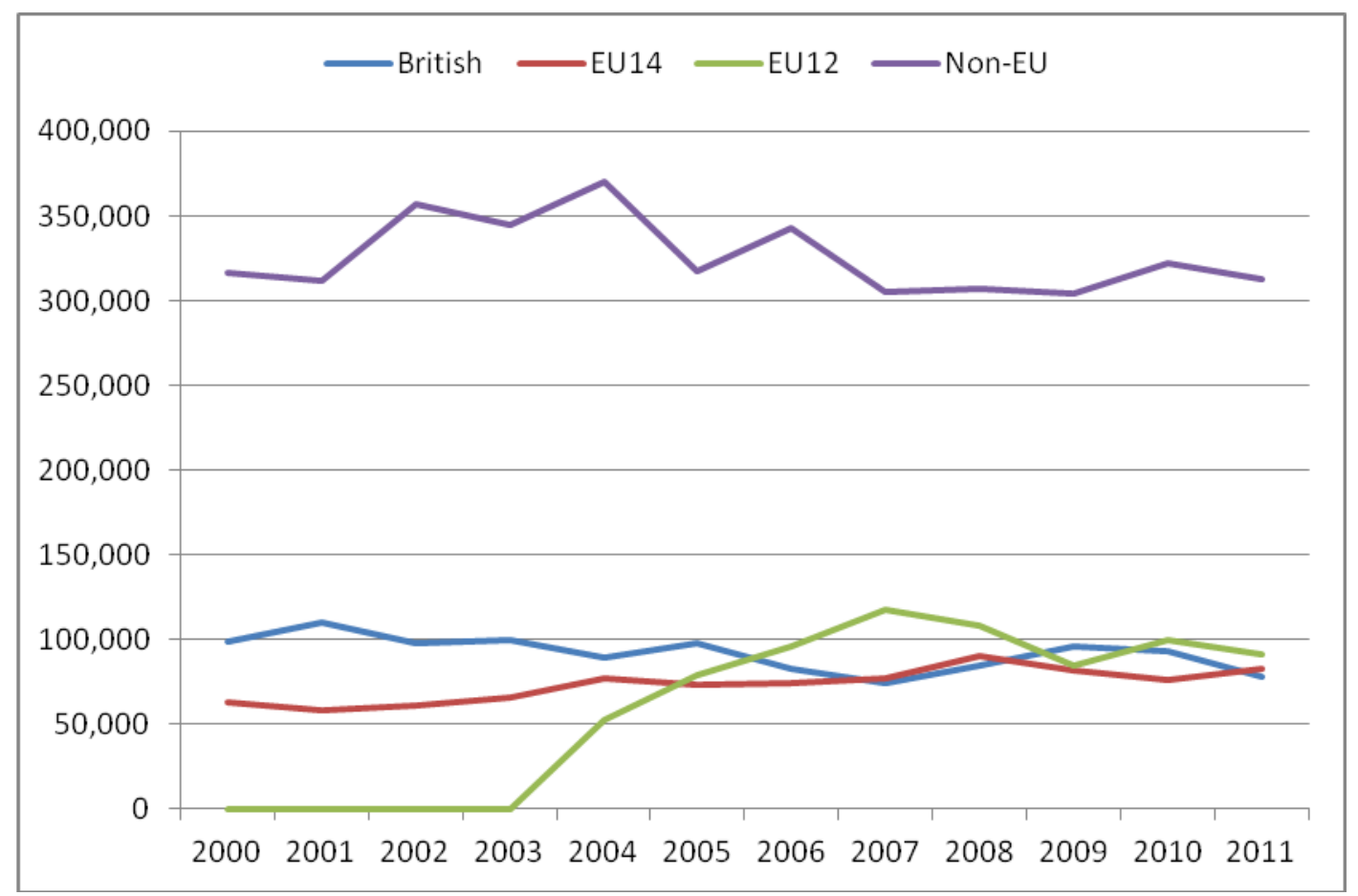

Source: ONS

The LTIM data also provide the main estimates of emigration from the UK. Figure 4 shows that the number of citizens from EU14 countries has remained at around the 50,000 mark since 2000. In contrast, return migration from the UK to the EU12 was fairly low until 2008 and then rose sharply in that year, with the estimated number of EU12 citizens leaving the UK more than three times higher than in 2007. Return migration to these countries has fallen since then and was below 50,000 in both 2010 and 2011. Emigration by citizens from non-EU countries has been at least 100,000 in each year since 2000 but these flows have been small in relation to immigration, which suggests a larger degree of permanent migration from non-EU countries, especially in comparison to migrants from the EU12. There was a fairly sharp decline in emigration by British citizens between 2006 and 2010, followed by a slight rise in 2011.

As mentioned previously, the LTIM estimates only relate to individuals intending to stay in the UK for at least a year and so do not capture short-term migration. This is important in the context of flows of European migrants to the UK since circular, seasonal and other types of temporary migrants are more likely to come from EU countries because of freedom of movement, as well as closer geographic proximity. Therefore in order to get a more complete picture of recent migration to the UK, that will also include temporary migrants, information from the National Insurance Number Registrations by Overseas Nationals (NINo) database, which is maintained by the Department of Work and Pensions (DWP) is now presented. This database contains information on overseas nationals registering for a national insurance number in the UK since 2002. The majority of registrants will have already taken up or are about to take up employment in the UK, including the self-employed, as well as 
recording some benefit claimants. The database should thus represent a relatively accurate record of new migrants entering the UK for the first time but it does not provide any information on individuals leaving the UK.

Figure 4: Long-Term Emigration from the UK by Citizenship Group

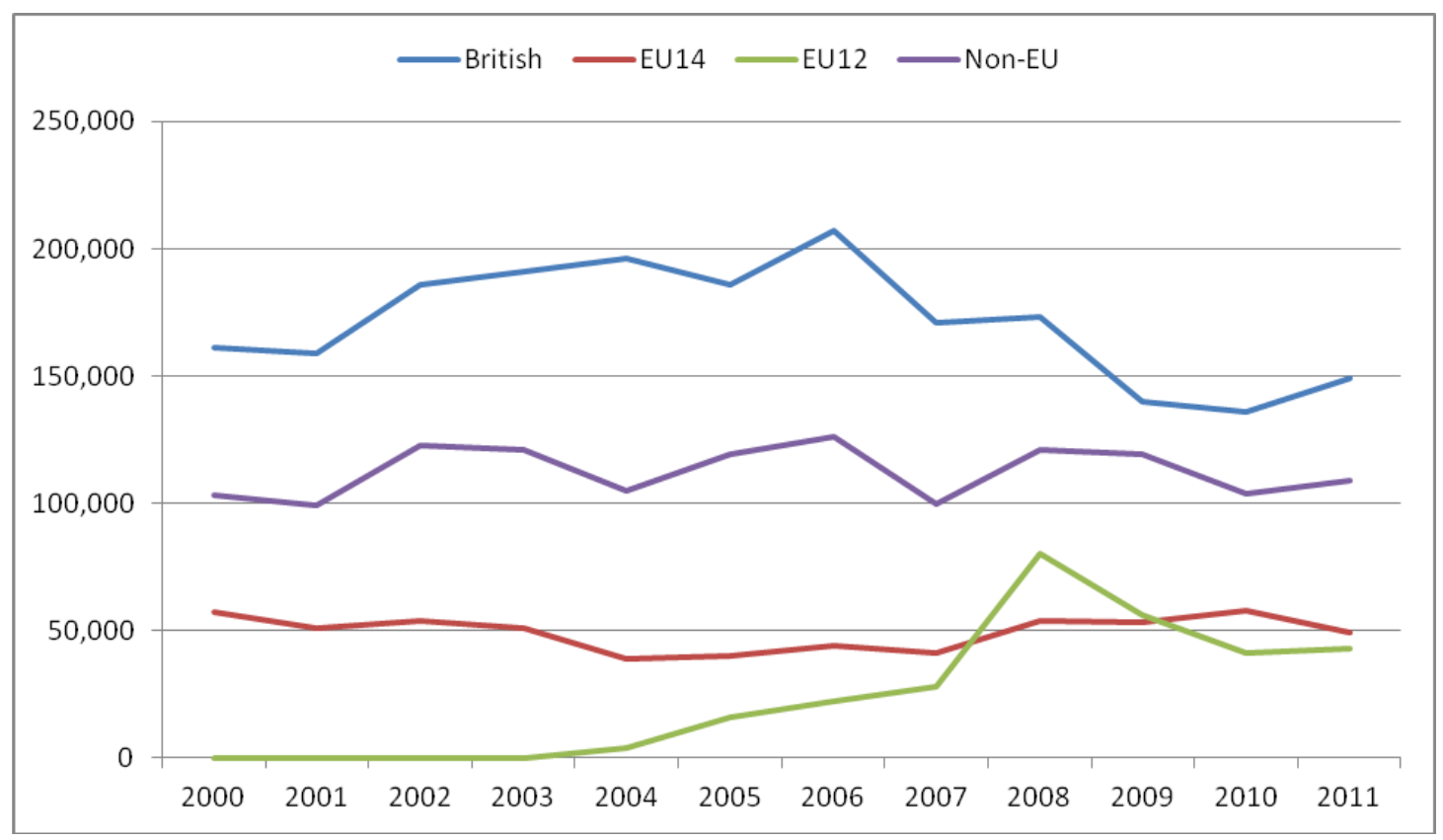

Source: ONS

Figure 5 shows NINo registrations in the UK by nationals from the three sending areas examined in Figures 1-4 for the period between 2002 and 2011. The most noticeable aspect of the figure is the very rapid growth in NINo registrations made by nationals from EU12 countries between 2004 and 2007. This is consistent with high levels of short-term migration from these countries given that this increase is far more marked than the fairly steady rise in long-term immigration shown in Figure 3. Other studies such as Pollard et al. (2008) confirm that this was the case. NINo registrations from EU12 countries fell quite sharply when the UK economy was in the grip of the recession but then increased in both 2010 and 2011. In contrast, registrations from the EU14 have displayed a fairly steady increase since 2002, although a more rapid rise in 2010 and 2011 can also be observed. Registrations from outside the EU also showed a steady rise up to 2010 before dipping in 2011, which may be related to the tougher migration stance taken by the Coalition government. 
Figure 5: NINo Registrations in the UK by Nationality Group

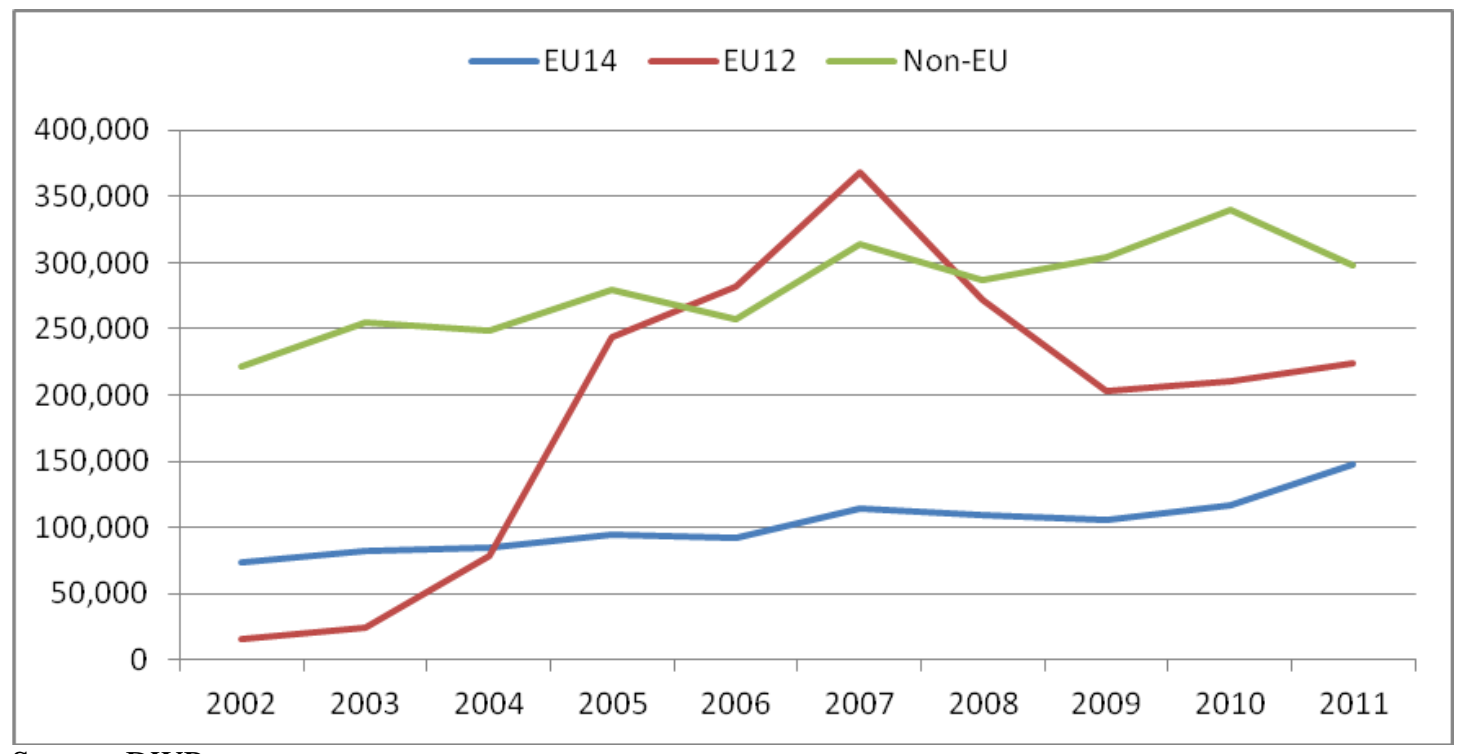

Source: DWP

In order to examine recent European migration flows to the UK more closely, Figure 6 splits the EU14 and EU12 each into two groups. For the former, these relate to registrants from Portugal, Italy, Ireland, Greece and Spain (PIIGS) - countries which were severely affected by the global financial crisis - and the Other EU14 countries. The other two groups shown in Figure 6 are the EU8 and other new member states (Malta, Cyprus, Bulgaria and Romania). The figure shows an increase in registrations from the PIIGS since 2007, which is particularly evident after 2009. The sharp increase and then decline in registrations from the EU8 is also clearly evident. There was a fairly large increase in registrations from other New-EU member states following the accession of Bulgaria and Romania in 2007, despite the transitional arrangements that were imposed by the UK government on migration from these countries. Registrations from other EU14 countries have also grown but at a fairly slow pace, rising from around 37,000 in 2002 to almost 54,000 in 2011. By way of comparison, registrations from the PIIGS increased from around the same level in 2002 to almost 94,000 in 2011.

Details on registrations from individual EU and selected non-EU countries are presented in Table A1 in the Appendix. The strong growth in registrations since 2009 from each of the EU member states most affected by the recession and Euro-crisis is clearly shown in the table. For example, NINo registrations from Spain and Greece more than doubled between 2009 and 2011 and increased by around 50\% for the Irish and Italians and a third for Portuguese nationals. The recent pattern of registrations from EU8 countries has been quite different. In particular, inflows of migrant workers from Poland have declined quite considerably since peaking in 2007, with registrations in 2009-11 around a third of the level seen in 2007 when more than 240,000 NINos were allocated to Polish nationals. A similar reduction in percentage terms was also seen in registrations from the Slovak Republic. In contrast, inflows from the Baltic states have increased since the recession, with registrations from Latvia, Lithuania and Estonia increasing by 171\%, 128\% and 62\% respectively between 2008 and 2011. NINo registrations from Bulgaria and Romania remained high but fairly stable from 2007 since inflows from these countries are regulated by 
the transitional arrangements. Registrations from Germany and France have also risen and these countries accounted for more than two-thirds of the registrations from other EU14 countries in 2011 compared to 60\% in 2002.

Figure 6: NINo Registrants in the UK by Grouped Country of Nationality

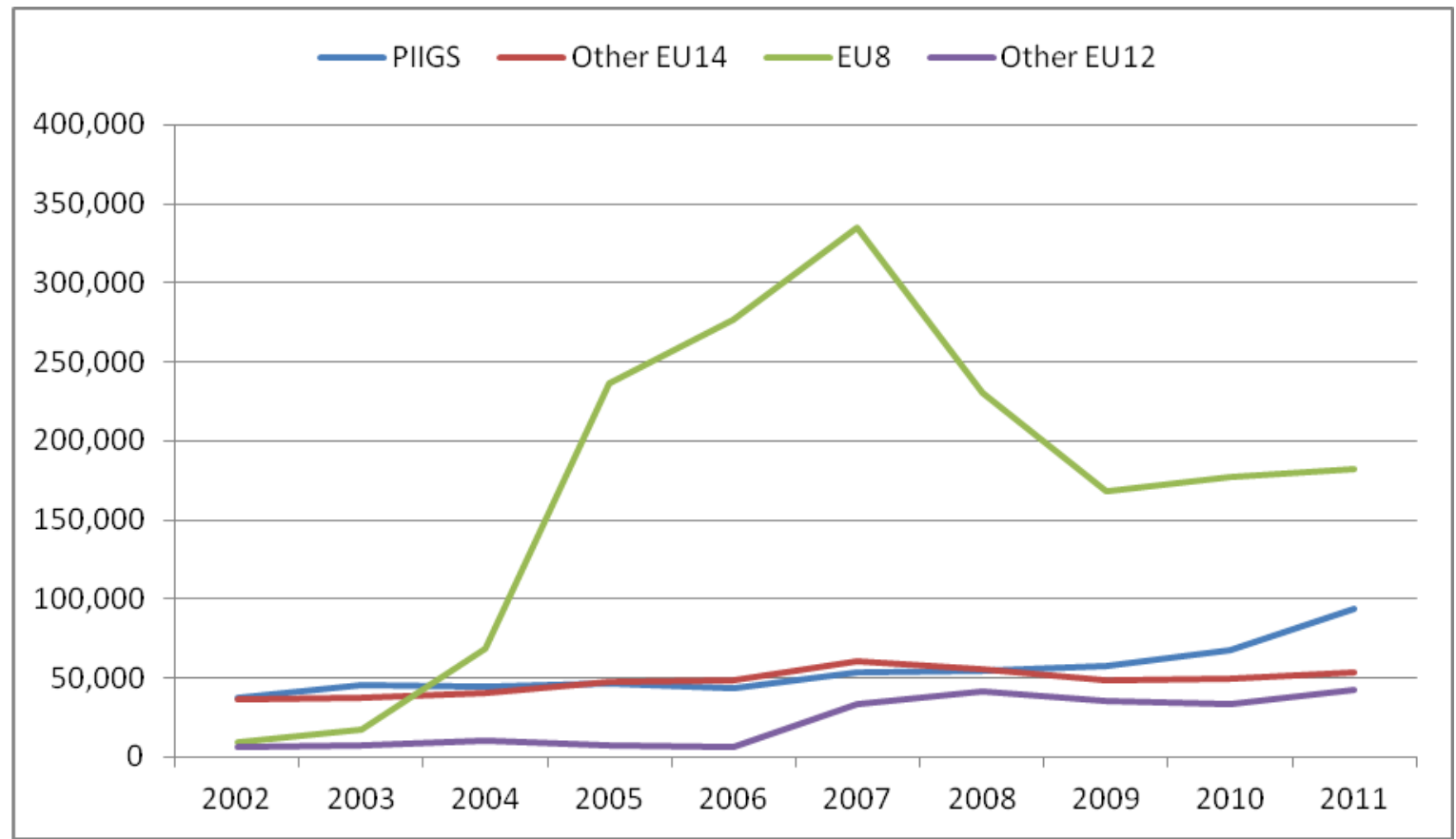

Source: DWP

The NINo database contains limited information on the characteristics of registrants specifically their gender, age band and area of residence in the UK. Table 1 reports changes in the broad characteristics of registrants from EU14 and EU12 countries and from outside of the EU across three periods: 2002-4, 2005-7 and 2008-11. These roughly correspond to pre-enlargement, post-enlargement and recession phases.

The table indicates that, while there is a slightly higher percentage of male registrants in each period, for all three groups new immigration is evenly split across genders. There have been some fluctuations though, with males accounting for around 56\% of NINo registrants from EU12 countries in 2005-7 and 55\% of non-EU registrants in 2008-11. The age structure of registrants from each of the three groups is also fairly similar, with around $80 \%$ of working age registrants under 35 . There are again some variations, with the 16-24 age group accounting for an increased percentage of registrants. This may be have been influenced by greater student numbers in work (part-time - especially for non-EU countries), although the majority of recent arrivals from the EU12 states tended not to be students. Registrants from the EU12 have become less concentrated in London, with only a quarter residing there in the middle period, which is far lower than the equivalent percentages for those from the EU14 and from outside the EU. ${ }^{10}$ As a result, EU12 migrants have become fairly evenly dispersed across the UK, which is consistent with the geographical analysis of data

\footnotetext{
${ }^{10}$ A relatively high percentage of individuals from the EU14 have registered as overseas residents, although this has declined in recent years. For example, almost 9,600 (13\%) registrants from EU14 countries registered from outside the UK in 2002 compared with 1,300 (1\%) in 2011.
} 
from the WRS undertaken by Bauere et al. (2007) and McCollum and Findlay (2011). In contrast, recent migrants from the EU14 have become more concentrated in London, where 54\% of registrants from these countries resided in 2008-11.

Table 1: Characteristics of NINo Registrants in the UK by Nationality Group

\begin{tabular}{|c|c|c|c|c|c|c|c|c|c|}
\hline & \multicolumn{3}{|c|}{ EU14 } & \multicolumn{3}{|c|}{ EU12 } & \multicolumn{3}{|c|}{ Non-EU } \\
\hline & $2002-4$ & 2005-7 & 2008-11 & $2002-4$ & $2005-7$ & 2008-11 & $2002-4$ & 2005-7 & 2008-11 \\
\hline \% Male & 50.2 & 51.5 & 52.0 & 51.1 & 56.3 & 53.9 & 51.2 & 52.2 & 54.8 \\
\hline \% Aged 16-24 & 36.9 & 36.2 & 40.3 & 36.4 & 41.8 & 43.3 & 31.6 & 34.7 & 37.5 \\
\hline \% Aged 25-34 & 44.3 & 43.9 & 40.2 & 46.7 & 40.1 & 34.7 & 48.6 & 47.6 & 45.0 \\
\hline \% Aged 35+ & 18.9 & 19.9 & 19.6 & 16.9 & 18.1 & 22.0 & 19.8 & 17.7 & 17.5 \\
\hline \% in London & 41.6 & 45.6 & 53.7 & 48.7 & 25.2 & 28.2 & 43.6 & 44.1 & 47.5 \\
\hline$\%$ in South/East & 27.7 & 24.6 & 21.4 & 26.4 & 28.0 & 28.1 & 23.2 & 22.4 & 20.1 \\
\hline \% in Midlands & 8.8 & 8.4 & 6.4 & 9.1 & 15.0 & 15.7 & 12.0 & 10.9 & 10.5 \\
\hline \% in North & 10.7 & 10.4 & 8.9 & 8.8 & 16.4 & 14.8 & 14.6 & 14.2 & 14.1 \\
\hline $\begin{array}{l}\text { \% in Devolved } \\
\text { Regions }\end{array}$ & 11.3 & 11.0 & 9.7 & 7.0 & 15.4 & 13.1 & 6.6 & 8.4 & 7.8 \\
\hline
\end{tabular}

Source: DWP

Notes: London refers to the Greater London region, South/East consists of the regions of the East of England, South East and South West, Midlands consists of the East and West Midlands, North consists of the North East, North West and Yorkshire \& the Humber, Devolved Regions consists of Northern Ireland, Scotland and Wales. The denominator used to calculate the regional percentages excludes registrants classified as overseas residents rather than living in the UK.

\section{Changing Socio-Economic and Labour Market Characteristics of Immigrants in the UK}

The previous section mainly focused on inflows of migrants to the UK. However, in order to obtain a more complete picture of how immigration to the UK has evolved over the past decade or so, especially in the light of changes affecting the economy, we now turn our attention to examining migration stocks. As well as considering how the size of immigrant groups has grown, we also analyse their socio-economic and labour market characteristics. This will be mainly undertaken using the Labour Force Survey (LFS), which is the main regular source of information for examining the socio-economic and labour market circumstances of sub-sections of the UK population. Data from the Annual Population Survey (APS), which incorporates respondents from the LFS but has a boosted sample size, will also be presented to obtain a more accurate indication of the size of particular immigrant groups.

Figure 7 describes changes between the first quarter of 2000 and the final quarter of 2011 in the estimated working age population for three immigrant groups: those born in the EU14, EU8 and in other countries. ${ }^{11}$ The figure shows that the number of immigrants from outside the EU has grown steadily since the start of the century, from around 1.5 million to over 2.6 million by the end of 2011. In line with data on

\footnotetext{
${ }^{11}$ These categories are examined since they are the ones that are used by the ONS to estimate working age populations from different immigrant groups on a consistent basis using the APS. The 2011 APS estimates are in line with those provided by the 2011 Census.
} 
migration flows to the UK, Figure 7 indicates that the population of working age EU8 immigrants was very small until just before 2004. It did, however, start to increase even before enlargement, with the estimates suggesting that there were less than 50,000 working age EU8 immigrants in the third quarter of 2003 but this had risen to more than 76,000 by the second quarter of 2004 and to almost 120,000 by the end of that year. The number of working age migrants from these countries then rose rapidly between 2005 and 2007 so that by the start of 2008, the estimated population of this group exceeded half a million. The estimated population of working age EU8 migrants stayed fairly constant at this level until the start of 2010 before rising again. By the end of 2011, there were estimated to be more than 700,000 working age migrants from the EU8 resident in the UK, which was slightly greater than the estimated figure from EU14 countries. The estimated immigrant population from the latter group of countries has been relatively constant, with only a small rise towards the end of the period despite the increase in inflows indicated in the NINo figures.

LFS data are now used to analyse the socio-economic and labour market characteristics of the same three immigrant groups that were defined in the previous section (EU14, EU12 and Non-EU) over three time periods: 2000-3; 2004-7 and 2008-11. The sample of LFS data that is examined in this section has been constructed by pooling 48 consecutive quarterly datasets, from 2000 to 2011. The dataset only includes respondents interviewed for the first time (wave 1) in order to avoid double-counting, in the light of wave 1 interviews being face-to-face and this wave having the highest response rates (Drinkwater et al., 2009). Table 2 presents information on key personal characteristics, whilst Table 3 reports a range of labour market outcomes for working age migrants.

Figure 7: Estimated UK Working Age Population by Immigrant Group

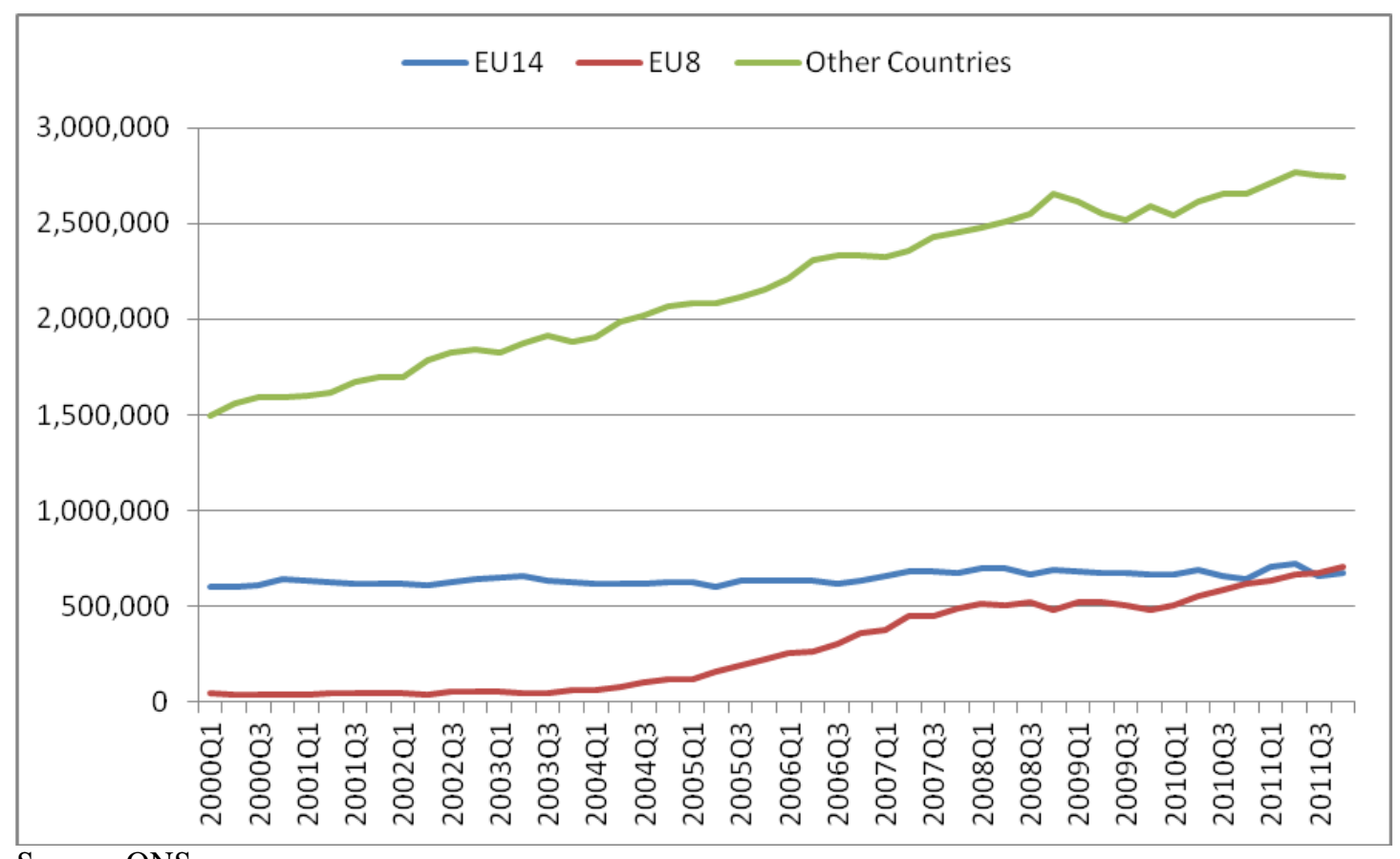

Source: ONS 
Table 2: Characteristics of Working Age Immigrants in the UK by Grouped Area of Birth

\begin{tabular}{|c|c|c|c|c|c|c|c|c|c|}
\hline & \multicolumn{3}{|c|}{ EU14 } & \multicolumn{3}{|c|}{ EU12 } & \multicolumn{3}{|c|}{ Non-EU } \\
\hline & $2000-3$ & 2004-7 & 2008-11 & $2000-3$ & 2004-7 & 2008-11 & $2000-3$ & 2004-7 & 2008-11 \\
\hline$\%$ Male & 46.4 & 47.9 & 47.1 & 45.1 & 50.0 & 47.0 & 48.3 & 48.2 & 48.5 \\
\hline \% Aged 16-24 & 14.3 & 12.6 & 13.6 & 13.3 & 24.2 & 19.1 & 13.1 & 12.5 & 12.4 \\
\hline \% Aged 25-34 & 27.3 & 26.7 & 25.2 & 25.1 & 41.1 & 51.0 & 26.8 & 27.5 & 26.8 \\
\hline \% Aged 35-49 & 31.8 & 35.4 & 37.8 & 38.5 & 23.5 & 22.1 & 40.6 & 39.3 & 39.7 \\
\hline \% Aged 50-59/64 & 26.7 & 25.4 & 23.4 & 23.1 & 11.2 & 7.8 & 19.5 & 20.7 & 21.1 \\
\hline \% in London & 28.5 & 26.0 & 26.5 & 48.6 & 32.5 & 23.7 & 42.7 & 37.6 & 35.6 \\
\hline \% in South & 33.7 & 34.3 & 33.6 & 29.1 & 26.7 & 27.7 & 23.0 & 25.1 & 24.9 \\
\hline$\%$ in Midlands & 11.2 & 10.4 & 10.7 & 7.5 & 14.2 & 15.7 & 13.3 & 14.7 & 15.1 \\
\hline$\%$ in North & 14.8 & 15.1 & 15.5 & 9.8 & 16.3 & 16.8 & 15.2 & 16.3 & 17.3 \\
\hline \% in Dev. Regions & 11.9 & 14.3 & 13.7 & 5.0 & 10.3 & 16.2 & 5.8 & 6.4 & 7.1 \\
\hline$\%$ arriving pre-1980 & 47.1 & 37.3 & 29.6 & 49.3 & 15.5 & 4.1 & 39.6 & 29.2 & 22.0 \\
\hline$\%$ arriving in 1980 s & 16.4 & 17.2 & 15.9 & 10.4 & 3.8 & 1.2 & 17.9 & 14.6 & 11.9 \\
\hline$\%$ arriving in 1990s & 26.5 & 21.9 & 23.0 & 26.5 & 9.9 & 5.4 & 29.7 & 23.6 & 20.5 \\
\hline$\%$ arriving 2000-3 & 10.0 & 14.1 & 10.4 & 13.8 & 16.2 & 10.6 & 12.8 & 21.6 & 19.2 \\
\hline \% arriving 2004-7 & - & 9.5 & 14.1 & - & 54.6 & 61.6 & _ & 11.0 & 18.4 \\
\hline$\%$ arriving 2008-11 & & & 6.9 & & & 17.2 & & & 8.0 \\
\hline \% Married & 54.5 & 53.0 & 50.3 & 67.7 & 49.1 & 47.9 & 68.7 & 68.3 & 68.3 \\
\hline \% with High Ed. & 28.9 & 31.7 & 37.0 & 25.8 & 33.5 & 36.0 & 32.2 & 35.6 & 39.9 \\
\hline \% with Medium Ed. & 22.0 & 23.4 & 23.8 & 28.7 & 42.2 & 46.5 & 26.1 & 25.0 & 25.5 \\
\hline \% with Low Ed. & 49.1 & 44.9 & 39.3 & 45.5 & 24.4 & 17.5 & 41.7 & 39.4 & 34.6 \\
\hline
\end{tabular}

Source: LFS

Notes: The High Education category relates to individuals leaving full-time education after the age of 20, the Medium Education category to those leaving between the ages of 18 and 20 and the Low Education category to those leaving under the age of 18.

Table 2 reports information for the same characteristics as shown in Table 1 (gender, age and region), as well as for some which are not available in the NINo database (marital status and years of education). In contrast to the flow statistics, there has been a slight majority of females amongst working age migrants for the three groups in each of the time periods apart from migrants from the EU12 in the immediate postenlargement period. The percentage of 25-34 year old migrants from new member states has also been increasing, with more than $50 \%$ in this age category in the final time period. As a result, the percentage of working age migrants aged over 50 in this migrant group fell from $23 \%$ to $8 \% .^{12}$ In contrast, the age structure of migrants from EU14 countries and from outside the EU was similar across the three periods. This was also true for the geographical distribution of migrants from these two groups, whereas migrants from EU12 countries became far more dispersed after enlargement, with less than a quarter living in London by the final period. The impact of immediate

\footnotetext{
${ }^{12}$ The composition of this group was quite different in the first period because of a higher proportion who were born in Cyprus and Malta pre-enlargement.
} 
post-enlargement flows of migrants from the EU12 to the UK is clearly shown in the table, with $62 \%$ of those interviewed in 2008-11 having arrived between 2004 and 2007. A lower percentage of migrants from the EU12 after enlargement were married but the percentage of married working age migrants from EU14 countries was only slightly lower in the final period. The percentage of highly educated individuals has increased for the three migrant groups, whilst the percentage of migrants with low levels of education has decreased for each. ${ }^{13}$ The decline observed for migrants from the EU12 is particularly noticeable, falling from $46 \%$ in $2000-3$ to $18 \%$ in $2008-11$.

\section{Table 3: Labour Market Outcomes of Working Age Immigrants in the UK by Grouped Area of Birth}

\begin{tabular}{|c|c|c|c|c|c|c|c|c|c|}
\hline & \multicolumn{3}{|c|}{ EU14 } & \multicolumn{3}{|c|}{ EU12 } & \multicolumn{3}{|c|}{ Non-EU } \\
\hline & 2000-3 & 2004-7 & 2008-11 & $2000-3$ & 2004-7 & 2008-11 & $2000-3$ & 2004-7 & 2008-11 \\
\hline Activity Rate & 75.6 & 76.3 & 77.8 & 67.9 & 83.2 & 85.0 & 65.6 & 68.0 & 69.7 \\
\hline Employment Rate & 71.4 & 72.6 & 72.7 & 63.5 & 78.1 & 80.6 & 60.1 & 62.7 & 63.4 \\
\hline Unemployment Rate & 5.5 & 4.9 & 6.6 & 6.5 & 6.2 & 5.2 & 8.3 & 7.7 & 9.0 \\
\hline Self-Employment Rate & 14.0 & 13.0 & 14.2 & 20.0 & 14.3 & 13.8 & 15.9 & 15.0 & 14.9 \\
\hline \multirow{3}{*}{$\begin{array}{l}\text { \% with Prof/Man Occs } \\
\text { \% with Intermediate Occs } \\
\text { \% with Low Skilled Occs }\end{array}$} & 33.4 & 35.4 & 38.7 & 27.8 & 13.1 & 9.9 & 32.7 & 32.4 & 32.7 \\
\hline & 33.4 & 34.1 & 33.6 & 34.0 & 26.9 & 26.2 & 33.6 & 32.3 & 29.9 \\
\hline & 33.3 & 30.6 & 27.8 & 38.3 & 60.1 & 64.0 & 33.8 & 35.3 & 37.4 \\
\hline \% in Prod./Manuf. & 15.2 & 14.3 & 12.4 & 14.4 & 22.2 & 25.7 & 14.3 & 12.5 & 10.0 \\
\hline$\%$ in Construction & 6.5 & 6.6 & 5.8 & 7.6 & 11.4 & 10.1 & 3.0 & 3.4 & 3.6 \\
\hline \% in Retail/Hospitality & 20.8 & 18.2 & 19.1 & 22.7 & 23.0 & 26.1 & 23.4 & 22.7 & 22.4 \\
\hline \% in Transport/Comms & 6.4 & 6.9 & 6.0 & 5.4 & 9.7 & 7.8 & 8.7 & 8.4 & 8.4 \\
\hline \% in Business/Finance & 18.4 & 18.9 & 21.6 & 14.7 & 12.5 & 13.4 & 18.3 & 18.4 & 19.1 \\
\hline \% in Public Services & 26.3 & 29.0 & 29.3 & 24.8 & 14.5 & 12.3 & 27.5 & 29.9 & 32.1 \\
\hline \% in Other Services & 6.4 & 6.1 & 5.8 & 10.4 & 6.7 & 4.6 & 4.9 & 4.9 & 4.4 \\
\hline \multirow[t]{2}{*}{ Average hourly earnings } & 12.27 & 12.98 & 13.49 & 12.05 & 8.27 & 7.79 & 12.33 & 12.28 & 12.50 \\
\hline & $(9.97)$ & (10.33) & (10.89) & $(10.60)$ & $(5.46)$ & $(4.61)$ & $(10.41)$ & $(9.72)$ & $(9.72)$ \\
\hline
\end{tabular}

\section{Source: LFS}

Notes: Hourly earnings are gross figures which are reported in pounds in May 2007 prices. The standard deviation of gross hourly earnings is reported in parentheses.

Table 3 contains details on a range of labour market outcomes. The first of these indicates that activity rates have risen for each group across the three periods. This increase was fairly small for EU14 and non-EU migrants but much larger for EU12 migrants following accession. In particular, the activity rate of migrants from the EU12 increased by more than 15 percentage points between 2000-3 and 2004-7. The activity rate for this group had risen to $85 \%$ by the final period, which is noticeably

\footnotetext{
${ }^{13}$ Educational categories have been constructed using the age left full-time education variable and the definitions are explained in the notes to Table 2. This table highlights the increasing levels of human capital possessed by immigrants to the UK. The introduction of the PBS implies that this will continue and the skills attainment of immigrants compared to the UK-born is likely to further widen.
} 
higher than it was for either EU14 or non-EU migrants. Activity rates have increased for both males and females in each of the three migrant groups across the three periods. However, there continues to be noticeable gender differences in activity rates amongst migrants groups in the UK. For example, the activity rates for EU12 migrants had risen to $91 \%$ for males and $79 \%$ for females in the 2008-2011 period, compared with equivalent rates of $80 \%$ and $60 \%$ for non-EU migrants. The same pattern is reflected in employment rates given that unemployment rates have generally been low for each group. As result, the employment rate for migrants from EU12 countries had increased to $81 \%$ by 2008-11, compared to $73 \%$ for EU14 migrants and $63 \%$ from outside the EU. The unemployment rate for migrants from the EU12 also decreased over the three periods and was just over $5 \%$ in the final period. ${ }^{14}$ In contrast, the unemployment rate for migrants from the EU14 and outside the EU increased between the second and third periods. The self-employment rate for these two groups was fairly similar in each of the three periods, whereas there was a large fall (6 percentage points) in the rate for migrants from EU12 countries in the pre and post-enlargement periods. This is a continuation of the trend noted by Clark and Drinkwater (2008), who attributed the relatively high self-employment rate for this group in the first period to the entry of entrepreneurs before restrictions on migrant workers were removed.

Although the majority of migrants from the EU12 have jobs, they are typically employed in low-skilled occupations. For example, over $64 \%$ of migrant workers from these countries had low-skilled jobs in the third period, compared to $28 \%$ for migrants from the EU14 and 37\% from outside the EU. By the final period, only $10 \%$ of migrants from the EU12 who were in employment had high skilled jobs. The corresponding figures for EU14 and Non-EU migrants were 39\% and 33\%. Given the high levels of educational attainment amongst EU12 migrants, as shown in Table 2, this may indicate that UK employers are keen to recruit such workers into low-skilled positions. The industrial distribution of employment amongst the three migrant groups is consistent with the figures on occupation. For example, 52\% of migrant workers from the EU12 had jobs in Production, Manufacturing, Retail and Hospitality in the final period compared with around 32\% from the other two groups. In contrast, the percentage of EU12 migrants in Business/Finance and Public Services is far lower.

Real earnings have risen for migrants from the EU14 over the three periods. The dispersion of earnings, as measured by the standard deviation, has also increased for this group. The real earnings of non-EU migrants have remained fairly constant, although the variability of earnings did increase in the final period. In contrast, the average earnings of EU12 migrants have declined considerably since enlargement, falling from a similar average to that observed for EU14 migrants in the first period to around $£ 4.70$ an hour lower in the second period. Real earnings further decreased for migrants from new member states in the final period. Moreover, the earnings distribution for this group has become very compressed post-enlargement, as shown by the low standard deviation. ${ }^{15}$

\footnotetext{
${ }^{14}$ This compares to a rate of around 7\% for those born in the UK in this period. The employment rate of the native born was also around 2 percentage points lower in 2008-11 than 2004-7.

${ }^{15}$ See Drinkwater et al. (2009) for a more detailed discussion of the earnings of recent immigrants to the UK, focusing particularly on Polish migrants. Furthermore, the spatial concentration of migrant groups and regional pay variations should be taken in account when making comparisons between the earnings of migrant groups in the UK.
} 
Table 4: Broad Occupation of Working Age Immigrants in the UK by Education Level and Grouped Area of Birth

\begin{tabular}{|c|c|c|c|c|c|c|c|c|c|}
\hline & \multicolumn{3}{|c|}{ EU14 } & \multicolumn{3}{|c|}{ EU12 } & \multicolumn{3}{|c|}{ Non-EU } \\
\hline & $2000-3$ & 2004-7 & 2008-11 & $2000-3$ & 2004-7 & 2008-11 & $2000-3$ & 2004-7 & 2008-11 \\
\hline $\begin{array}{l}\text { \% with High Ed. in } \\
\text { prof/man occs }\end{array}$ & 59.5 & 59.6 & 60.4 & 47.1 & 23.3 & 16.7 & 53.5 & 50.9 & 50.0 \\
\hline $\begin{array}{l}\% \text { with High Ed. in } \\
\text { intermediate occs }\end{array}$ & 29.0 & 29.5 & 30.4 & 32.5 & 26.9 & 27.9 & 30.6 & 30.2 & 28.5 \\
\hline $\begin{array}{l}\text { \% with High Ed. in } \\
\text { low skilled occs }\end{array}$ & 11.5 & 11.0 & 9.2 & 20.4 & 49.8 & 55.4 & 15.8 & 18.8 & 21.5 \\
\hline $\begin{array}{l}\text { \% with Medium Ed. } \\
\text { in prof/man occs }\end{array}$ & 28.7 & 32.1 & 33.7 & 24.0 & 5.9 & 6.2 & 26.0 & 25.6 & 24.4 \\
\hline $\begin{array}{l}\% \text { with Medium Ed. } \\
\text { in intermed occs }\end{array}$ & 39.1 & 40.3 & 38.1 & 34.5 & 26.7 & 25.5 & 39.6 & 37.3 & 34.4 \\
\hline $\begin{array}{l}\text { \% with Medium Ed. } \\
\text { in low skilled occs }\end{array}$ & 32.2 & 27.5 & 28.2 & 41.5 & 67.4 & 68.3 & 34.4 & 37.1 & 41.2 \\
\hline $\begin{array}{l}\text { \% with Low Ed. in } \\
\text { prof/man occs }\end{array}$ & 17.9 & 17.6 & 17.2 & 17.6 & 12.1 & 5.5 & 17.7 & 17.5 & 16.2 \\
\hline $\begin{array}{l}\text { \% with Low Ed. in } \\
\text { intermed occs }\end{array}$ & 34.7 & 35.3 & 35.5 & 36.4 & 29.2 & 24.5 & 33.9 & 32.3 & 29.9 \\
\hline $\begin{array}{l}\% \text { with Low Ed. in } \\
\text { low skilled occs }\end{array}$ & 47.4 & 47.1 & 47.3 & 46.0 & 58.8 & 70.1 & 48.4 & 50.2 & 54.0 \\
\hline
\end{tabular}

Table 4 reports the extent of skill-mismatch amongst the three different migrant groups using the LFS. The degree of mismatch appears to be highest for migrants from the EU12 since over a half of highly-educated individuals from these countries worked in low-skilled occupations following EU enlargement. This compared with less than $10 \%$ of migrants from the EU14 and 22\% from outside the EU. This may partly be explained by the lower English language proficiency of many migrants from accession countries, as well as the typically shorter durations of their stays in the UK (Clark and Drinkwater, 2008). There was also a higher percentage of low-skilled workers from these countries amongst migrants with medium and low levels of education. There has not been much change since the start of the recession in the occupational attainment of particular educational groups amongst migrants from the EU14. However, the occupational outcomes for non-EU migrants deteriorated for each educational category in 2008-11, despite the introduction of the PBS.

Finally in this section we discuss the adjustment in labour market outcomes for migrant groups over the recession. Although Table 3 indicates that unemployment rates have risen for EU14 and non-EU migrants in recent years, Wadsworth (2010) reports that in contrast to previous recessions a similar change in unemployment was experienced by immigrants and the UK-born in the most recent recession. In particular, Wadsworth (2010) shows that unemployment differentials between immigrants and natives have typically risen during recessions and decreased during 
periods of growth in the UK since 1979. However in the most recent recession, similar increases in unemployment were observed for immigrants and natives, both for males and females. A possible explanation for this may be the increased levels of skills possessed by recent immigrants who have entered the UK. Dustmann, Glitz and Vogel (2010) also use LFS data to examine cyclical variations in employment and wages between immigrants and natives. They report that the unemployment response to economic shocks for immigrants is much higher than that experienced by natives within particular skill groups in the period between 1981 and 2005. Similar results are reported for immigrants and natives in Germany. Dustmann, Glitz and Vogel (2010) also find that the differential responses to wages over the economic cycle were far smaller.

\section{Labour Market and Fiscal Impacts of Recent Immigration to the UK}

Most studies of the impact of immigration on the UK labour market have employed some variant of the spatial correlation approach (Altonji and Card, 1991; Borjas, 1999). The essential idea is to examine the effect of an increased supply of immigrants in a particular labour market where this is usually defined to be a geographical area. The average labour market outcomes of native or resident workers are typically regressed on a variable reflecting the immigrant supply shock and the estimated coefficient on this variable is assumed to measure the labour market effect of immigration. Controls can be included for other characteristics of the immigrant groups such as age or human capital which might be thought to affect outcomes. Despite this, the approach is subject to a number of potential criticisms. For example, using geographical areas as the unit of analysis may underestimate the effects of immigration if natives respond to an influx of migrants by leaving areas where migrants cluster. Similarly the immigrant supply shock may not be exogenous with respect to the random error if immigrants choose location on the basis of their perceptions of labour market success. Various modifications have been made to the simple spatial correlations approach to address these criticisms including the use of instrumental variables and the definition of alternative units of analysis such as cells defined across skill groups rather than geographical regions.

The broad message from such studies in the UK is that there has been little impact on the employment and wages of native or resident workers. However, his conclusion holds only in the aggregate. Positive and negative effects have been found in particular segments of the market and there is also evidence that in the recent economic downturn immigration may be worse for the labour market outcomes of natives/residents than in a strongly growing economy.

Considering the impact on employment first, Dustmann et al. (2005) adopt the spatial correlation approach using data from the UK Labour Force Survey (LFS) from the period 1983-2000. Their geographical unit of analysis is the standard region and their definition of immigrant status reflects nativity (UK-born vs. non-UK born). Overall, they find no statistically significant effect of immigrant inflows on the employment of UK-born workers at the aggregate level. However, amongst certain sub-groups in the labour market there is a statistically significant, negative effect. For example, inflows of workers with intermediate qualifications, defined as O-Levels or equivalent (a lower level of qualification than that required to enter higher education), are found to reduce the employment of similarly qualified UK-born workers. MAC (2012) 
interprets Dustmann et al.'s estimates as suggesting that an inflow of 10,000 immigrant workers with intermediate qualifications would reduce the employment of similarly qualified UK-born workers by around 2,000. Using more recent data from DWP administrative records in 2007, Reed and Latorre (2009) also apply the spatial correlation approach and find no overall effect of immigration flows on the employment of the resident working age population. Notably, Reed and Latorre's data will include more EU8 migrants than those used by Dustmann et al. (2005) thus the lack of an employment effect may be thought of as a better guide to the impact of further EU enlargement on the UK workforce than previous studies.

One important caveat to these findings regarding employment is that conclusions drawn about the effect of immigration on the labour market may depend on the state of the business cycle. MAC (2012) investigates this using a spatial correlation approach with LFS data up to 2010. The longer time period allows the analysis to be carried out separately for sub-periods when there was a positive output gap and subperiods when there was a negative output gap. The contrast between these is striking with no significant effect on the employment of the UK-born during expansionary sub-periods but a significant negative effect during sub-periods when there is a negative output gap.

Gilpin et al. (2006) analyse the effect on native unemployment of EU8 migration and again the approach is based on spatial correlations. Unlike the studies of employment referred to above, however, Gilpin et al. are able to use a much lower level of aggregation: 409 Local Authority Districts (LADs) as opposed to the regional measure (less than 20 geographical units). This is possible because their data are drawn from administrative records, captured when EU8 migrants registered on the WRS, and a claimant count measure of unemployment. Gilpin et al. estimate a number of models in which the key independent variable is the proportion of WRS registrations relative to the working age population in a LAD and the dependent variable is the change in the unemployment rate (as measured by those claiming Job Seekers Allowance) in the LAD. They control for a number of other factors including the potential endogeneity of the migration variable and estimate a number of static and dynamic specifications of the model. In no case do they find any evidence of a statistically significant association between EU8 migration and the unemployment rate in a LAD. In the light of the findings from MAC (2012) described in the previous paragraph, however, it is worth noting that Gilpin et al.'s data refer to changes in the claimant count between November 2004 and November 2005, a period when the UK labour market and economy were still relatively buoyant.

Variants of the spatial correlation approach have also been applied to the impact of immigration on the UK wage distribution. Studies such as Dustmann et al. (2005, 2013), Nickell and Saleheen (2008), Lemos and Portes (2008) and Manacorda et al. (2012) all find relatively small effects on wages in the aggregate, however, there are some statistically significant associations in particular sections of the labour market or for particular types of worker. For example Dustmann et al. (2013) extend their earlier analysis (Dustmann et al., 2005) by considering how immigration affects wages, not just at the mean (log) wage, but across the whole of the wage distribution. In contrast to earlier studies, the "average" effect of immigration on wages, measured here at either the mean or the median of the distribution, is positive and significant, however there is variation in this effect at different quantiles. At the lower end of the 
distribution immigration is found to have a negative effect on the wages of natives while at the upper end a positive effect exists. Dustmann et al. (2013) argue that the positive findings are consistent with a labour market in which native and immigrant workers are imperfectly substitutable in the production process. They further suggest that the extensive "downgrading" observed by immigrants to the UK, i.e. the tendency to work in occupations for which they are overqualified, may contribute to the positive effect.

Nickell and Salaheen (2008) also address downgrading and note that increases in the immigrant share of employment are U-shaped with respect to the occupational distribution. In other words, immigrants tend to concentrate in the upper and lower tails of the wage distribution. Nickell and Salaheen argue that the reasons for this may be important in determining the impact of migration on wages. At the upper end, migration may be more demand-driven with firms paying higher wages to attract highly qualified staff while, at the other end of the distribution, supply shocks, such as the impact of EU enlargement, may be more important as a source of migration flows and hence one would expect to find a bigger impact on wages here. Their empirical work supports this view. At the mean of the wage distribution a 10 percentage point increase in the share of immigrants is estimated to reduce wages by $0.4 \%$. However in the case of workers in "semi/unskilled services - that is, in care homes, bars, shops, restaurants, cleaning, for example” (Nickell and Salaheen, 2008, p. 19), a 10 percentage point increase in the migrant share leads to a $5.2 \%$ reduction in wages. This extremely large wage effect emphasises the importance of considering separate segments of the labour market.

Manacorda et al. (2012) explicitly adopt the idea that there may be imperfect substitution between native and immigrant workers. Within a Constant Elasticity of Substitution production function framework they use data on the relative employment levels and relative wages of immigrants and natives within labour market cells defined by age and education to directly estimate the elasticity of substitution between natives and immigrants. The data clearly reject the hypothesis of perfect substitutability between native and immigrant labour and Manacorda et al. argue that this may help to explain why empirical work has largely failed to find any strong evidence of a negative effect on native wages. Essentially, immigrant workers are supplying a significantly different stream of productive services compared to natives. A corollary of this is that an expansion of the supply of immigrant workers will have the biggest negative effect on the wages of existing immigrants. A similar conclusion is reached in Brücker et al. (2014) using a slightly different empirical approach.

The impact of immigration on public finances and the welfare state depends on a number of characteristics of the migrants themselves including primarily their age and labour market status. To the extent that migrants tend to be young, unattached and in employment, it might be expected that they would be contributing to the exchequer through taxation and not consuming welfare services. Similarly, those who stay for short durations are unlikely to draw on health or other public services. On the other hand, migrants who bring dependents or who acquire dependents in the UK and those who stay permanently are more likely to consume the services provided by the welfare state. Thus estimates of the impact of migration on the public sector reflect the demographic composition of the migrant groups concerned. Recent research commissioned by the MAC (2012) has estimated the consumption of public services 
by different migrant groups in comparison to the native population. Some estimates of the consumption of public services per adult in 2009/10 prices are reproduced in Table 5 for various population groups. The table suggests that migrants, as a whole, consume somewhat less in terms of personal services (including social work, personal care, disability and some child welfare services) and health compared to nonmigrants. This is driven by the lower average age of migrants. Note particularly how recent migrants, whose average age is lower than all migrants, consume only around $62 \%$ of the health consumption of non-migrants whereas the respective figure for all migrants is $89 \%$. The exception to this general rule of lower consumption for migrants is in the area of state funded education services where all migrants consume $33 \%$ more than non-migrants per head. However, this reflects the methodology used to calculate the estimates whereby the expenditure on the children of migrants is counted to the migrant parent irrespective of where the child was born. All of the variation in education expenditure by group is explained by the average household composition of the groups.

Table 5: Consumption of Government Services by the UK Migrant Population

\begin{tabular}{lccc}
\hline \hline & $\begin{array}{c}\text { Education } \\
\text { Services }\end{array}$ & $\begin{array}{c}\text { Personal Social } \\
\text { Services }\end{array}$ & $\begin{array}{c}\text { Health } \\
\text { Services }\end{array}$ \\
\hline Non-migrants & 1,662 & 720 & 2,765 \\
\hline $\begin{array}{l}\text { All migrants } \\
\begin{array}{l}\text { Migrants with less } \\
\text { than 5 years }\end{array}\end{array}$ & 2,216 & 708 & 2,450 \\
$\begin{array}{l}\text { residence } \\
\text { Non-EEA migrants }\end{array}$ & 1,403 & 508 & 1,717 \\
\hline \hline
\end{tabular}

Source: MAC (2012)

Notes: Figures in the table are $£$ per head of adult population in 2009/10 prices. For a fuller definition of the expenditure categories and migrant groups see MAC (2012).

Consumption of government services, however, is only one side of the fiscal balance sheet relating to immigration and a number of studies have investigated whether the net contribution of immigrants is positive or negative. Here, some measure of the monetary value of the consumption of services is subtracted from an estimate of the contribution of the relevant migrant groups to the exchequer. For the UK such work generally finds a small positive effect with immigrants generally seen as making a net positive contribution to the government budget. Such studies include Gott and Johnston (2002), Sriskandarajah et al. (2005) and Rowthorn (2008). To give a flavour of the results, Rowthorn (2008) concludes that immigrants make a net contribution of around $£ 0.6$ billion per annum to the economy but there is a wide range of variation around this in other studies depending on the particular methodology used.

One criticism of such studies is that they are essentially static in nature. In other words they look only at the contemporaneous contributions to, and withdrawals from, the budget surplus of given stocks of migrants in a particular year or years. This neglects the fact that immigration is inherently a dynamic process and that long-term immigration implies a future flow of payments to, and withdrawals from, the government. However the full analysis of the dynamic behaviour of immigrants is cloaked in uncertainty regarding how long immigrants will stay in the UK, their future 
patterns of household and family formation, their labour market trajectories and so on. Any such analysis is therefore highly dependent on the assumptions made about how immigrants will behave in the future. The behaviour of previous cohorts is unlikely to be a good guide here given the different source countries and characteristics of current immigrant flows compared to past flows.

A related issue is the treatment of the children of immigrants and whether or not their consumption of public services should be treated as government expenditure on immigrants despite the fact that they themselves may have been born in the UK. How such expenditure is allocated can in practice turn a net positive contribution into a negative one (Vargas-Silva, 2011).

Dustmann, Frattini and Halls (2010) specifically examine the fiscal impact of EU8 migration to the UK using data from the LFS between 2004 and 2009. They find a strong positive fiscal contribution from EU8 migrants with a ratio of tax revenues to expenditures of 1.35. This was attributable to the relatively high employment rates and younger age of the migrant group compared to the resident population. These factors made up for the fact that EU8 migrants tended to be working in sectors and occupations for which they were overqualified and were hence accepting wages which were lower than one might expect given their levels of human capital. In the context of the fiscal contribution of immigrants it is also worth noting that government policy in the UK has specifically limited the extent to which migrants are entitled to claim certain types of welfare benefits. EU8 migrants were excluded from certain tax credits until they had registered with the government and from all of the main types of social security benefit until they had worked for over 12 months in the UK. (Dustmann, Frattini and Halls, 2010).

\section{Conclusion}

Although there has been a slowdown in inflows of migrants to the UK in recent years, large numbers of people continue to arrive. Some of the decline appears to have been the outcome of reduced flows as a result of the recession, although this reduction is unlikely to have been as rapid as the Coalition government would have liked given their stated intention to lower immigration from the 'hundreds of thousands to the tens of thousands'. The introduction of the PBS, with further modifications, as well as changes to the admission of students may help to achieve this objective. Immigration from EU member states continues to be high, although there has been a change in the countries from where migrants originate from. In particular, there has been an increase in migration from the member states most affected by the recession, especially Spain and Italy in numerical terms, and a reduction from EU8 countries since 2007, especially Poland, which is partly the result of their improving economy. However, other factors such as an appreciation in the zloty relative to the pound and increased migration to other member states following the relaxation of transition arrangements (Pollard et al., 2008) are also contributing factors. Therefore, despite the sluggish performance of the UK economy in recent years, immigrants have continued to enter the UK but the balance of where they originate from has also been clearly influenced by the relative performance of different European economies.

The socio-economic characteristics and labour market outcomes of immigrants have also changed over the past decade. This appears to be more the result of migration 
policy decisions with regards to EU enlargement, especially that migrants from EU8 countries were granted more or less free access to the labour market. In addition to the very large flows of migrants from new member states who entered the UK, these migrants typically had high employment rates but also low occupational attainment and hence low earnings. This is in spite of the high percentage of this group having high levels of education, as measured by age left full-time education. As a result of the young age profile and high employment rates of recent EU migrants to the UK, it is estimated that they have made a positive net fiscal contribution and not had an adverse impact on the aggregate labour market outcomes of natives. However, large migration flows to particular areas or skill groups can produce losers, as well as winners, amongst different sections of the native population.

\section{References}

Altonji, J. G. and Card, D. (1991), "The effects of immigration on the labor market outcomes of less skilled natives”, in J. M. Abowd and R. B. Freeman (eds), Immigration, Trade and Labor, University of Chicago Press, Chicago.

Borjas, G. J. (1999), “The economic analysis of immigration”, in O. Ashenfelter and D. Card (eds), Handbook of Labor Economics, Vol. 3, Elsevir, Amsterdam.

Bauere, V., Densham, P., Millar, J. and Salt, J. (2007), "Migrants from Central and Eastern Europe: Local geographies”, Population Trends, 129, 7-19.

Brücker, H., Jahn, E. and Upward, R. (2014), "Migration and imperfect labor markets: Theory and comparative evidence from Denmark, Germany and the UK”, European Economic Review, 66, 205-225.

Clark, K. and Drinkwater, S. (2008), "The labour market performance of recent migrants”, Oxford Review of Economic Policy, 24, 495-516.

Devitt, C. (2012), "Labour migration governance in contemporary Europe. The UK case”, Fieri Working Paper.

Drinkwater, S., Eade, J. and Garapich, M. (2009), "Poles apart? EU enlargement and the labour market outcomes of immigrants in the UK”, International Migration, 47, 161-190.

Dustmann, C., Casanove, M., Fertig, M., Preston, I. and Schmidt, C. (2003), The Impact of EU Enlargement on Migration Flows, Home Office Online Report No. 25/03.

Dustmann, C., Fabbri, F. and Preston, I. (2005), "The impact of immigration on the British labour market”, Economic Journal (Features), 115, F324-F341.

Dustmann, C., Frattini, T. and Halls, C. (2010), “Assessing the fiscal costs and benefits of A8 Migration to the UK”, Fiscal Studies, 31, 1-41. 
Dustmann, C., Glitz, A. and Vogel, T. (2010), "Employment, wages, and the economic cycle: Differences between immigrants and natives", European Economic Review, 54, 1-17.

Dustmann, C., Frattini, T. and Preston, I. (2013), “The effect of immigration along the distribution of wages”, Review of Economic Studies, 80, 145-173.

Gilpin, N., Henty, M., Lemos, S., Portes, J. and Bullen, C. (2006), "The impact of free movement of labour from Central and Eastern Europe on the UK labour market", Department of Work and Pensions Working Paper No. 29.

Gott, C. and Johnston, K. (2002), “The migrant population in the UK: Fiscal effects”, Home Office Research, Development and Statistics Occasional Paper No. 77.

Gregg, P. and Machin, S. (2012), "What a drag: The chilling impact of unemployment on real wages”, Resolution Foundation Briefing.

(http://www.resolutionfoundation.org/media/media/downloads/What_a_drag_1.pdf)

Gregg, P. and Wadsworth, J. (2010), "Employment in the 2008-2009 recession”, Economic and Labour Market Review, 4(8), pp. 37-43.

Kangasniemi, M., Mas, M., Robinson, C. and Serrano, L. (2012), “The economic impact of migration: productivity analysis for Spain and the UK”, Journal of Productivity Analysis, 38, 333-343.

Lemos, S. and Portes, J. (2008), "The impact of migration from the new European Union member states on native workers”, Department for Work and Pensions Working Paper No. 52.

MAC (2012), Analysis of the Impacts of Migration, Migration Advisory Committee, London.

Manacorda, M., Manning, A. and Wadsworth, J. (2012), “The impact on immigration on the structure of wages: Theory and evidence from Britain”, Journal of the European Economic Association, 10, 120-151.

McCollum, D and Findlay, A. (2011), "Trends in A8 migration to the UK during the recession”, Population Trends, 145, 77-89.

ONS (2012), Background Notes and Guidelines for Long-Term International Migration Estimates, Office for National Statistics Online publication.

(http://www.ons.gov.uk/ons/taxonomy/index.html?nscl=Long-term+Migrants)

Nickell, S. and Saleheen, J. (2008), "The impact of immigration on occupational wages: Evidence from Britain”, Federal Reserve Bank of Boston Working Paper No. 08-6.

Pollard, N., Latorre, M. and Sriskandarajah, D. (2008), Floodgates or Turnstiles? Post EU Enlargement Migration Flows to (and from) the UK, Institute for Public Policy Research, London. 
Rowthorn, R. (2008), “The fiscal impact of immigration on advanced economies”, Oxford Review of Economic Policy, 24, 561-581.

Reed, H. and Latorre, M. (2009), "The economic impacts of migration on the UK labour market”, Economics of Migration Working Paper 3, Institute for Public Policy Research, London.

Sriskandarajah, D., Cooley, L. and Reed, H. (2005), Paying their Way: The Fiscal Contribution of Immigrants in the UK, Institute for Public Policy Research, London.

Vargas-Silva, C. (2011), "The fiscal impact of immigration in the UK”, Migration Observatory Briefing, University of Oxford.

Wadsworth, J. (2010), “The UK labour market and immigration”, National Institute Economic Review, No. 213, R35-R42 
APPENDIX

Table A1: NINo Registrants in the UK by Country of Nationality, 2002-2011

\begin{tabular}{|c|c|c|c|c|c|c|c|c|c|c|c|}
\hline & 2002 & 2003 & 2004 & 2005 & 2006 & 2007 & 2008 & 2009 & 2010 & 2011 & Total \\
\hline PIIGS & 37,180 & 45,030 & 44,490 & 46,400 & 43,190 & 53,850 & 54,690 & 57,210 & 67,620 & 93,890 & 543,550 \\
\hline Greece & 3,070 & 3,040 & 2,750 & 3,310 & 3,250 & 3,660 & 2,940 & 2,750 & 3,270 & 5,600 & 33,640 \\
\hline Ireland & 8,090 & 9,170 & 9,270 & 10,200 & 9,510 & 10,580 & 10,550 & 11,050 & 13,920 & 17,040 & 109,380 \\
\hline Italy & 7,710 & 8,120 & 8,160 & 10,350 & 11,060 & 15,730 & 16,460 & 16,880 & 18,490 & 24,900 & 137,880 \\
\hline Portugal & 7,910 & 12,620 & 13,850 & 11,710 & 9,700 & 12,040 & 12,980 & 12,230 & 12,080 & 16,350 & 121,450 \\
\hline Spain & 10,400 & 12,080 & 10,460 & 10,830 & 9,670 & 11,840 & 11,760 & 14,300 & 19,860 & 30,000 & 141,200 \\
\hline Other EU14 & 36,740 & 37,490 & 40,400 & 47,720 & 48,980 & 60,560 & 55,330 & 48,820 & 49,210 & 53,880 & 479,160 \\
\hline Austria & 1,170 & 1,180 & 1,220 & 1,460 & 1,380 & 1,780 & 1,570 & 1,230 & 1,350 & 1,390 & 13,740 \\
\hline Belgium & 1,560 & 1,440 & 1,430 & 1,740 & 1,730 & 2,200 & 2,080 & 1,880 & 1,960 & 2,190 & 18,190 \\
\hline Denmark & 2,110 & 2,230 & 2,070 & 2,200 & 2,170 & 2,120 & 1,770 & 1,730 & 1,700 & 1,860 & 19,970 \\
\hline Finland & 1,330 & 1,300 & 1,250 & 1,330 & 1,270 & 1,440 & 1,300 & 1,110 & 1,260 & 1,290 & 12,880 \\
\hline France & 13,120 & 12,890 & 13,470 & 16,290 & 17,470 & 22,960 & 22,260 & 19,920 & 19,680 & 23,450 & 181,520 \\
\hline Germany & 8,840 & 9,610 & 10,410 & 12,790 & 13,470 & 16,770 & 14,900 & 12,500 & 12,220 & 12,730 & 124,230 \\
\hline Luxemburg & 40 & 50 & 50 & 60 & 70 & 80 & 90 & 60 & 60 & 80 & 650 \\
\hline Netherlands & 4,820 & 5,280 & 6,890 & 7,380 & 7,060 & 7,770 & 6,720 & 5,710 & 6,030 & 5,970 & 63,620 \\
\hline Sweden & 3,750 & 3,510 & 3,610 & 4,470 & 4,360 & 5,440 & 4,640 & 4,680 & 4,950 & 4,920 & 44,360 \\
\hline EU8 & 9,520 & 16,890 & 68,650 & 236,350 & 276,540 & 334,590 & 230,910 & 167,670 & 176,820 & 181,960 & $1,699,930$ \\
\hline Czech Republic & 1,050 & 1,170 & 4,670 & 13,020 & 10,960 & 12,290 & 10,470 & 8,710 & 7,260 & 7,700 & 77,290 \\
\hline Estonia & 160 & 190 & 1,060 & 3,000 & 2,160 & 1,680 & 1,440 & 1,950 & 2,240 & 2,340 & 16,200 \\
\hline Hungary & 680 & 850 & 2,550 & 7,690 & 8,910 & 13,870 & 14,680 & 13,750 & 14,200 & 17,910 & 95,100 \\
\hline Latvia & 350 & 580 & 3,700 & 13,500 & 11,420 & 9,320 & 7,970 & 20,120 & 28,280 & 21,580 & 116,830 \\
\hline
\end{tabular}




\begin{tabular}{|c|c|c|c|c|c|c|c|c|c|c|c|}
\hline Lithuania & 1,430 & 3,140 & 10,710 & 29,100 & 24,200 & 22,240 & 16,500 & 21,770 & 37,740 & 37,560 & 204,390 \\
\hline Poland & 4,740 & 9,490 & 38,440 & 144,740 & 192,210 & 242,530 & 152,320 & 85,860 & 74,850 & 84,140 & $1,029,340$ \\
\hline Slovak Republic & 890 & 1,270 & 6,850 & 24,710 & 26,220 & 32,080 & 26,980 & 15,150 & 11,910 & 10,400 & 156,460 \\
\hline Slovenia & 220 & 200 & 670 & 590 & 460 & 580 & 550 & 360 & 340 & 330 & 4,320 \\
\hline Other EU12 & 5,820 & 7,470 & 10,320 & 7,770 & 5,960 & 33,270 & 41,100 & 35,130 & 33,130 & 42,180 & 222,160 \\
\hline Bulgaria & 3,710 & 4,320 & 5,720 & 3,110 & 1,940 & 12,250 & 15,880 & 13,540 & 12,450 & 14,460 & 87,380 \\
\hline Cyprus & 320 & 300 & 580 & 1,070 & 1,000 & 1,160 & 1,200 & 1,060 & 1,200 & 1,440 & 9,340 \\
\hline Malta & 220 & 220 & 390 & 590 & 580 & 690 & 580 & 470 & 520 & 480 & 4,740 \\
\hline Romania & 1,570 & 2,630 & 3,630 & 3,000 & 2,440 & 19,170 & 23,440 & 20,060 & 18,960 & 25,800 & 120,700 \\
\hline Australia & 17,570 & 17,590 & 16,620 & 22,670 & 22,520 & 25,740 & 21,270 & 16,370 & 14,770 & 15,220 & 190,330 \\
\hline Bangladesh & 6,330 & 7,520 & 7,550 & 8,010 & 8,810 & 10,990 & 8,930 & 15,480 & 18,820 & 10,000 & 102,430 \\
\hline China & 7,320 & 12,690 & 13,330 & 13,160 & 11,450 & 15,230 & 15,560 & 13,710 & 15,730 & 16,600 & 134,780 \\
\hline India & 20,750 & 29,290 & 32,930 & 43,350 & 43,310 & 53,820 & 52,150 & 69,150 & 79,780 & 59,820 & 484,330 \\
\hline Nigeria & 5,140 & 7,000 & 7,970 & 11,910 & 10,790 & 14,680 & 15,090 & 17,960 & 17,070 & 15,680 & 123,300 \\
\hline Pakistan & 15,720 & 15,250 & 20,630 & 21,940 & 21,020 & 27,930 & 22,700 & 21,890 & 35,470 & 46,840 & 249,390 \\
\hline Philippines & 10,890 & 10,990 & 8,700 & 8,640 & 8,360 & 8,480 & 8,750 & 10,980 & 9,630 & 5,500 & 90,920 \\
\hline South Africa & 17,000 & 18,390 & 19,170 & 23,690 & 17,630 & 14,320 & 12,580 & 8,440 & 3,860 & 3,500 & 138,580 \\
\hline USA & 7,220 & 7,510 & 7,810 & 9,480 & 9,390 & 11,780 & 10,960 & 9,320 & 9,850 & 10,650 & 93,960 \\
\hline Other Non-EU & 113,440 & 128,420 & 113,500 & 116,910 & 104,590 & 131,200 & 118,950 & 120,590 & 134,900 & 114,640 & $1,197,090$ \\
\hline Unknown & 700 & 680 & 710 & 560 & 510 & 440 & 590 & 490 & 840 & 690 & 6,220 \\
\hline All Nationalities & 311,340 & 362,210 & 412,780 & 618,560 & 633,050 & 796,880 & 669,560 & 613,210 & 667,500 & 671,050 & $5,756,130$ \\
\hline
\end{tabular}
Source: DWP 